\title{
Larval aquatic and terrestrial mites infesting parthenogenetic Ischnura hastata (Odonata: Coenagrionidae) from the Azores islands
}

\author{
M. O. Lorenzo-Carballa $\cdot$ C. D. Beatty $\cdot$ R. Haitlinger $\cdot$ \\ A. G. Valdecasas $\cdot$ C. Utzeri $\cdot$ V. Vieira $\cdot$ A. Cordero-Rivera
}

Received: 13 January 2011/Accepted: 22 February 2011/Published online: 6 March 2011

(C) Springer Science+Business Media B.V. 2011

\begin{abstract}
We report here the prevalence of parasitism by water mites (Arrenurus sp.) and terrestrial mites (Leptus killingtoni) on parthenogenetic Ischnura hastata (Odonata: Coenagrionidae) from the Azores islands. Leptus killingtoni was only found on the island of Pico, and the prevalence of infestation was highly variable among the different ponds studied, ranging from 0 to $41 \%$. Leptus killingtoni was observed on three of the four odonate species from the archipelago: I. hastata, I. pumilio, and Sympetrum fonscolombii, all of them new hosts for this species. Aquatic mites have been found parasitizing I. hastata females on the island of São Miguel. The prevalence of mite parasitism by Arrenurus sp. on I. hastata was very low, ranging from $12 \%$ (2003) to $1 \%$ (2008), and in most of the studied ponds, no mites were found attached to females. Although I. hastata coexists with a sexual congener species in the Azores (I. pumilio), they are syntopic in only a small fraction of ponds. Therefore, a comparison between I. hastata and I. pumilio was insufficient to test the predictions of the Red Queen Hypothesis, and further research on
\end{abstract}

M. O. Lorenzo-Carballa $(\bowtie) \cdot$ C. D. Beatty · A. Cordero-Rivera

Grupo ECOEVO, Departamento de Ecoloxía e Bioloxía Animal, Universidade de Vigo,

EUET Forestal, Campus Universitario A Xunqueira s/n, 36005 Pontevedra, Spain

e-mail: olalla.lorenzo@uvigo.es

C. D. Beatty

Department of Biology, Santa Clara University, 500 El Camino Real, Santa Clara, CA 95060, USA

R. Haitlinger

Institute of Biology, Department of Systematics and Ecology of Invertebrates, Wrocław University of Environmental and Life Sciences, 51-631 Wrocław, Kożuchowska 5b, Poland

A. G. Valdecasas

Museo Nacional de Ciencias Naturales, CSIC, c/José Gutiérrez Abascal, 2., 28006 Madrid, Spain

C. Utzeri

Dipartimento di Biologia e Biotecnologie “Charles Darwin”, Università "La Sapienza”, Viale dell'Università 32, 00185 Rome, Italy

V. Vieira

Departamento de Biologia \& Grupo da Biodiversidade dos Açores (CITA-A), Rua da Mãe de Deus, Universidade dos Açores, Apartado 1422, PT, 9501-801 Ponta Delgada, Açores, Portugal 
parasitism rates in both species needs to be done. In any case, the low prevalence of mite parasitism found in the Azores, coupled with the fact that most of the populations in the archipelago are almost free from competitors and predators, could explain the persistence of these I. hastata parthenogenetic populations, despite their low levels of genetic variation.

Keywords Odonata Ischnura hastata $\cdot$ Mite ectoparasitism $\cdot$ Arrenurus · Leptus killingtoni $\cdot$ Parthenogenesis

\section{Introduction}

Aquatic mites belonging to the genera Arrenurus (Arrenuridae), Hydryphantes (Hydryphantidae) and Limnochares (Limnocharidae) (Acari: Hydrachnida), are among the most prevalent ectoparasites affecting adult dragonflies and damselflies (Corbet 1999; Zawal and Dyatlova 2008). The aquatic, hexapod larvae of water mites attach phoretically to the lastinstar odonate larvae, and during the emergence of the adult, the mites move to the thorax or abdomen of the dragonfly, where they remain attached feeding on the host's body fluids throughout their parasitic phase. After engorgement, the mite larvae drop from their host and start the aquatic phase of their life cycle (Corbet 1999). In addition to water mites, terrestrial mites belonging to the genera Charletonia and Leptus (Acari: Parasitengona) have also been recorded as parasites of odonates (Turk 1945; Southcott 1966, 1999; Haitlinger 1987; Zheng 1996; Grant and Samways 2007). In this case, the terrestrial mite larvae actively seek out and crawl onto adult Odonata when they are perched on the vegetation.

Parasite loads can be very high in some odonate populations, with large numbers of mites found on a single individual. For instance, Andrés and Cordero (1998) found that $98 \%$ of teneral individuals in a population of the damselfly Ceriagrion tenellum (Villers, 1789) were parasitized and the average load was 55 mites per individual. Ectoparasitic mites are known to negatively affect host population dynamics, through reductions in survivorship (Robinson 1983; Braune and Rolff 2001), mating success (Andrés and Cordero 1998), and alteration of host's activity patterns such as dispersal (Reindhart 1996; Conrad et al. 2002). Thus, they constitute important selective forces for odonates.

The interaction between hosts and parasites is currently considered a major force underlying the persistence of sexual reproduction. In accordance with the Red Queen Hypothesis (Van Valen 1973; Bell 1982; Ridley 1995) which suggests that organisms are constantly under selection from an ever-changing environment, it has been suggested that sexually reproducing organisms are better able to respond to parasites through the creation of new genotypes. Thus, asexuals would be expected to show higher parasitism rates than sexually reproducing organisms, due to their lower levels of genetic diversity and inability to create novel genotypes through recombination (Hamilton et al. 1990). Testing the predictions of the Red Queen Hypothesis is difficult, because the ideal model for such research is a comparison of parasitism in related forms reproducing sexually and asexually. The tests made until now generally supported the idea that asexuality is disadvantageous when parasites constitute strong selective forces (Lively et al. 1990; Moritz et al. 2010; reviewed for plants by Clay and Kover 1996), but in some cases the evidence is contrary to this idea (Hanley et al. 1995). A recent review of the assumptions of this hypothesis has argued that new experimental data and an increased theoretical effort are still needed (Salathé et al. 2008). 
Ischnura hastata (Say, 1839) (Odonata, Coenagrionidae) is a New World damselfly species, widely distributed from Canada to South America (Westfall and May 1996). It has also colonized the Azores archipelago in the Atlantic Ocean, where it reproduces exclusively through parthenogenesis (Cordero Rivera et al. 2005; Lorenzo-Carballa and Cordero-Rivera 2009). The genetic analyses of the parthenogenetic populations from the islands have shown a very low clonal diversity (Lorenzo-Carballa et al. submitted), which makes I. hastata a good model to test the predictions of the Red Queen Hypothesis.

With this initial aim, we sampled several localities at different islands within the Azores archipelago, to study the prevalence (number of infected hosts/number of host examined) of mite parasitism in I. hastata females and compare this with rates of parasitism in I. pumilio (Charpentier, 1825), the other coenagrionid species found in the archipelago.

We found larvae of water mites (Arrenurus sp.) and terrestrial mites [Leptus killingtoni (Turk, 1945)] infesting odonates in the Azores islands. Here, we provide detailed morphological data on these mite species, together with details on the new hosts and locality records. Although the prevalence of mite parasitism was not high enough to test the predictions of the Red Queen Hypothesis, we provide data on ectoparasitism rates in I. hastata, and we address the potential implications of parasitism in this species, given its unique reproductive strategy among the Odonata.

\section{Materials and methods}

Patterns of mite parasitism in Ischnura hastata

In July 2003, we observed ectoparasitic mites on I. hastata females at the pond Lagoa do Landroal, in the island of Pico. In July-August 2008 we visited this and several other ponds in this island, to study the prevalence of mite parasitism on I. hastata and to compare it with infestation rates on I. pumilio, the other coenagrionid species found in the archipelago, which reproduces sexually (see Table 1 for a list of sampled locations). Infestation rates were assessed visually, and the number of mites on each individual was recorded with the aid of a hand lens. Following examination, some parasitized damselflies were preserved in absolute ethanol for subsequent mite identification and photography. Some of the specimens were prepared for Scanning Electron Microscopy (SEM).

Prevalence of mite parasitism was also studied in a population in São Miguel island over 15 different days between 27 July and 24 August 2008, during the course of a markrecapture experiment (Lorenzo-Carballa et al. 2009). Each female captured during the study was examined for mites, and the number of mites on each individual was determined with the aid of a hand lens. As with the populations from Pico, some parasitized hosts were preserved in absolute ethanol for later mite identification and photography, and some specimens were also prepared for SEM.

Additional data on mite parasitism within parthenogenetic populations of I. hastata were obtained by counting the mites on females collected at several ponds in the islands of Flores, Faial, Pico, Terceira, Sao Miguel, Corvo and Santa Maria during the course of our expeditions to the Azores in the years 2003 and 2008 (see Table 2 for a list of sampled locations). These females were collected with the aid of a hand net, sweeping the vegetation close to the shore of the ponds, where they were mostly encountered. After sweeping, females were preserved in absolute ethanol, and the number of mites was later recorded in the laboratory under a binocular microscope. For a comparison with sexual populations, we assessed the rate of mite parasitism in samples of I. hastata previously 
collected from several populations in Colombia, Cuba, Mexico and the US (see Table 4 for a list of sampled locations).

\section{Mite species description}

Before slide preparation, mite larvae were removed from their hosts using forceps. Single mites, as well as the host body parts with the mites attached, were prepared for SEM.

For SEM, samples were subjected to increasing concentrations of ethanol as follows: $30,50,70,80,90$ for $30 \mathrm{~min}$ each; and then placed in absolute ethanol for $30 \mathrm{~min}$ for two changes. After dehydration, ethanol samples were placed in a series of amyl-acetate:ethanol dilutions as follows: 1:3, 1:1; $3: 1$ for 30 min each; and then placed in 100\% amylacetate for $30 \mathrm{~min}$ for two changes. Finally, samples were subjected to critical point drying to complete the dehydration process. In order to view specimens, they were first attached with double-sided carbon tape to aluminum stubs so that they could be coated with gold in a sputter-coating apparatus (Emitech K550X). The surface topography of mites was viewed at $10 \mathrm{kV}$ in a Philips XL 30 scanning electron microscope.

Mite larvae found on I. hastata from Pico Island were identified by Ryszard Haitlinger as Leptus killingtoni. Diagnosis for this species was given by Southcott (1992) (Fig. 1). The species was first described by Turk (1945) without many important details. Later, Southcott (1992) made a new description of the species, including some figures. Unfortunately, metric data were based only on a single specimen from Great Britain. Further metric data from this species in North-West Spain were given by Haitlinger (2006). Thus,
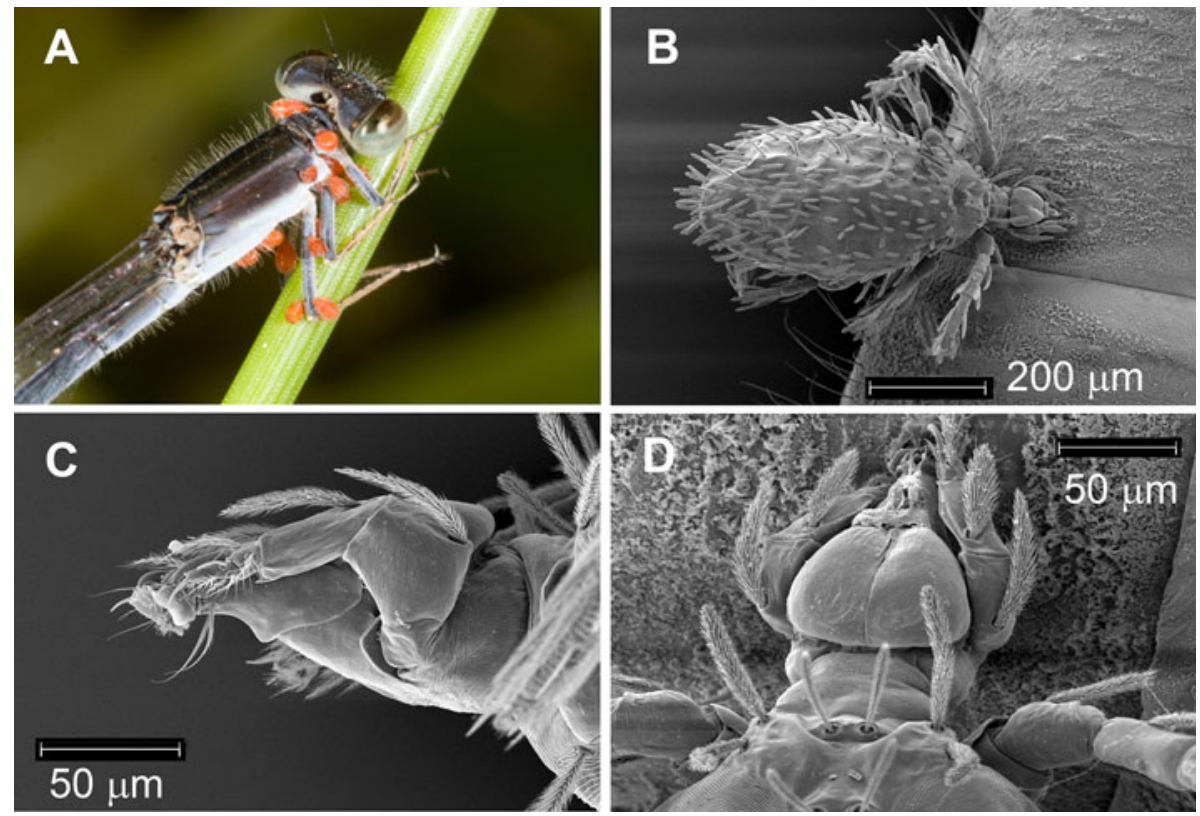

Fig. 1 a Adult female Ischnura hastata from Lagoa do Landroal (Pico), July 2008. This specimen had at least 13 larvae of Leptus killingtoni, some of which are not engorged. b Dorsal view of a L. killingtoni larva (Scanning Electron Microscopy, SEM). c Lateral view of the head and mouth of a Leptus larva (SEM). d Detail of the head and the attachment to the cuticle of the damselfly (SEM) 

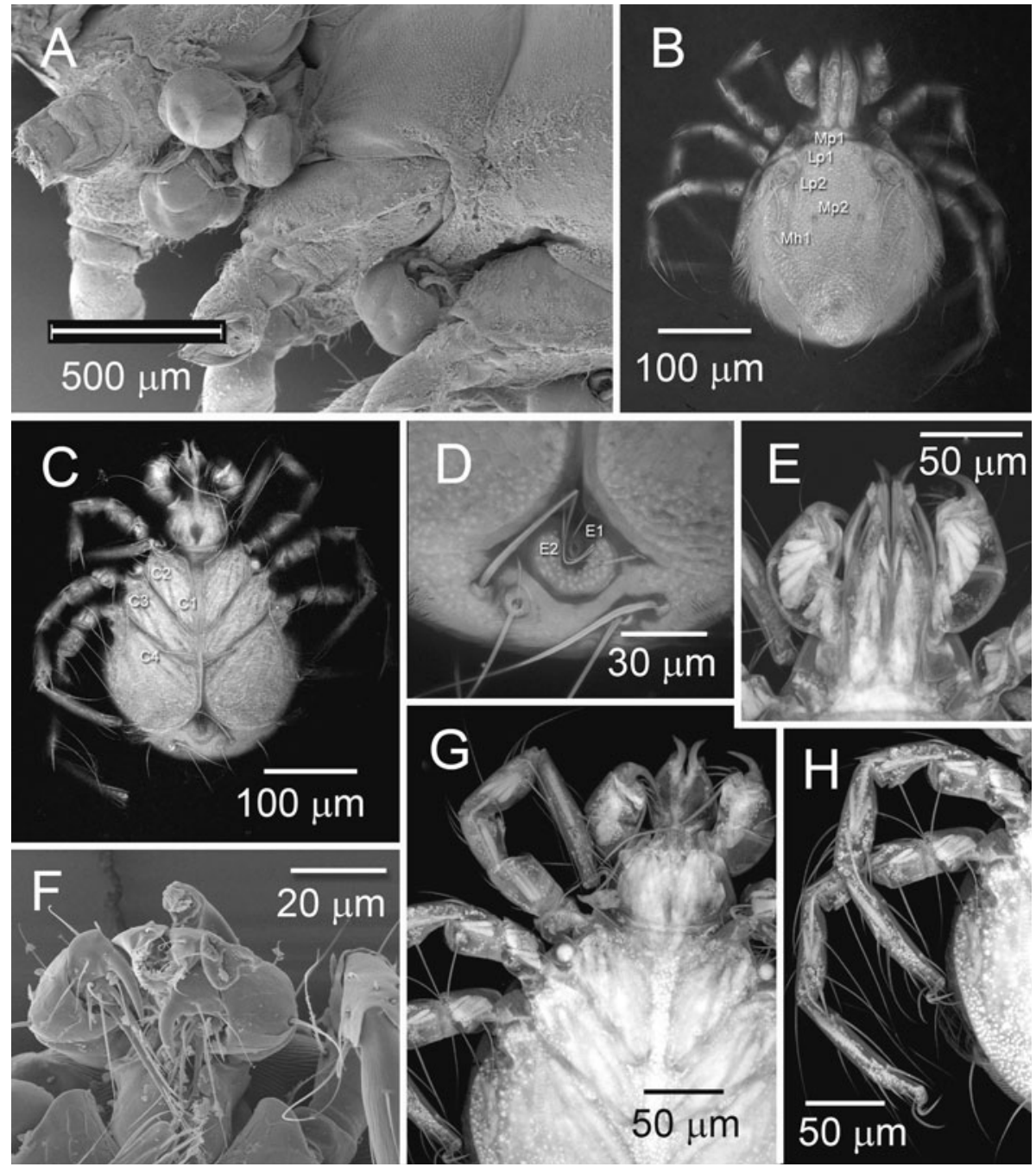

Fig. 2 a Two larvae of Arrenurus sp. on the coxae of Ischnura hastata (Scanning Electron Microscopy, SEM). b Dorsal view of a non-engorged larva of Arrenurus sp. (Laser Scanning Confocal Microscopy, LSCM, maximum intensity projection, MIP). c Ventral view of a non engorged larva of Arrenurus sp. (LSCM, MIP). d Detail of Excretory plate (LSCM, alpha blended of two sets of MIP images). e Chelicerae (LSCM, MIP). f Pedipals last segments (SEM). g First leg (LSCM, MIP). h Second and third leg (LSCM, MIP)

our data from L. killingtoni collected in the Azores complement the morphological description of this species.

Ten mite larvae were mounted on slides using Berlese's medium. Each specimen was observed under a Jenaval microscope (Carl Zeiss) using an objective $40 \times 0.6500 / 0.17-\mathrm{A}$, and a measuring ocular GF-Pw $10 \times$ was used to take measurements of the relevant taxonomic structures of these larvae. Terminology, abbreviations and standard data are based on the system described by Southcott (1992) and Haitlinger (2006). 
Table 1 Prevalence of parasitism by Leptus killingtoni on Ischnura hastata and I. pumilio at different ponds sampled in Pico island in 2008. Listed are: pond name, number of individuals examined $(n)$, prevalence of parasitism $(\mathrm{P})$ and range in mite load (I)

\begin{tabular}{|c|c|c|c|c|c|c|}
\hline \multirow[t]{2}{*}{ Date } & \multirow[t]{2}{*}{ Pond } & \multicolumn{2}{|l|}{$n$} & \multicolumn{2}{|l|}{$\mathrm{P}^{\mathrm{a}}$} & \multirow[t]{2}{*}{$\mathrm{I}$} \\
\hline & & Males & Females & Males & Females & \\
\hline \multicolumn{7}{|c|}{ Ischnura hastata } \\
\hline \multirow[t]{6}{*}{ July } & Cabeço da Lagoinha & n.a & 83 & n.a. & 0.17 & $1-3$ \\
\hline & Lagoa do Landroal & n.a & 134 & n.a. & 0.41 & $1-12$ \\
\hline & Lagoa do Caiado & n.a & 4 & n.a. & 0 & - \\
\hline & Large pond East Lagoa do Peixinho & n.a & 27 & n.a. & 0.04 & 1 \\
\hline & Small pond E Lagoa do Peixinho & n.a & 32 & n.a. & 0.06 & 1 \\
\hline & Unnamed pond & n.a & 63 & n.a. & 0 & - \\
\hline \multirow[t]{2}{*}{ August } & Cabeço do Caveiro & n.a & 423 & n.a. & 0.01 & 1 \\
\hline & Lagoa do Gato & n.a & 619 & n.a. & 0.04 & $1-2$ \\
\hline \multicolumn{7}{|c|}{ Ischnura pumilio } \\
\hline \multirow[t]{6}{*}{ July } & Cabeço da Lagoinha & 0 & 0 & - & - & - \\
\hline & Lagoa do Landroal & 26 & 69 & 0.23 & 0.35 & $1-4$ \\
\hline & Lagoa do Caiado & 26 & 52 & 0.13 & 0.15 & $1-4$ \\
\hline & Large pond East Lagoa do Peixinho & 24 & 44 & 0 & 0.04 & 1 \\
\hline & Small pond E Lagoa do Peixinho & 5 & 11 & 0.09 & 0 & 1 \\
\hline & Unnamed pond & 1 & 0 & 0 & - & - \\
\hline \multirow[t]{2}{*}{ August } & Cabeço do Caveiro & 0 & 1 & - & 0 & - \\
\hline & Lagoa do Gato & 17 & 10 & 0 & 0 & - \\
\hline
\end{tabular}

${ }^{a}$ Prevalence is presented here as a proportion

Mite larvae found on I. hastata from São Miguel island were initially identified by Antonio G. Valdecasas as belonging to the clade Hydrachnidia (water mites), which is known to parasitize aquatic insects when the mites are in the larval stage. Although there has been a considerable increase in our knowledge of water mite larval taxonomy (Martin 2006; Zawal 2008a; Smith et al. 2009 and references therein) even today a larva of an unknown female cannot be confidently identified to species. Three water mite larvae were transferred to temporary glycerin slides. Each specimen was placed on a special aluminum slide with an open circle in the middle. A Thermo Shandon $24 \times 40 \# 1.5$ coverslip was added to the aluminum slide as a base, and a Zeiss/Scott $18 \times 18 \# 1.5$ coverslip with a declared thickness of $0.170 \pm 0.001 \mathrm{~mm}$ was used as a cover to minimize light aberrations. This particular preparation procedure allows Laser Scanning Confocal Microscopy (LSCM) acquisition in both the dorsal and ventral views. LCSM acquisition was carried out using a Leica TCS SPE at $10 \times 0.30$ N.A., $20 \times 0.70$ N.A., $40 \times$ dry 0.75 N.A. and $63 \times$ gli 1.30 N.A. at an excitation wavelength of $488 \mathrm{~nm}$, and a wide emission wavelength range between 500 and $590 \mathrm{~nm}$ was used to collect as much fluorescence as possible. The acquisition resolution ranged between $1,024 \times 1,024$ and 2,048 $\times 2,048$ pixel. Image stacks were processed using FIJI (available at http://www.pacific.mpi-cbg.de/wiki/ index.php/Fiji) and Mipav (available at http://www.mipav.cit.nih.gov/). Alpha blended and maximum intensity projections (MIP) final images were checked for gamma correction and contrast with Photoshop CS3. No other manipulation of the images was carried out. 
Table 2 Prevalence of parasitism by Arrenurus sp. in parthenogenetic Ischnura hastata populations. Listed are: year of sample collection, island, pond name, number of females examined $(n)$, prevalence of parasitism (P) and range in mite load (I)

\begin{tabular}{|c|c|c|c|c|c|}
\hline Year & Island & Pond & $n$ & $\mathrm{P}^{\mathrm{a}}$ & I \\
\hline \multirow[t]{8}{*}{2003} & Flores & Caldeira da Lomba & 11 & 0 & - \\
\hline & Pico & Lagoa do Landroal & 10 & 0 & - \\
\hline & Faial & Caldeira & 25 & 0 & - \\
\hline & Terceira & Lagoa do Ginjal & 32 & 0 & - \\
\hline & & Lagoa do Negro & 20 & 0 & - \\
\hline & Sao Miguel & Lagoa do Carvão & 17 & 0.12 & 2 \\
\hline & & Furnas & 1 & 0 & - \\
\hline & Corvo & Caldeira & 3 & 0 & - \\
\hline \multirow[t]{7}{*}{2008} & Santa Maria & Ribeira do Sancho & 2 & 0 & - \\
\hline & Pico & Lagoa do Landroal & 18 & 0 & - \\
\hline & Sao Miguel & Lagoa do Carvão & 35 & 0 & - \\
\hline & & Lagoa do Fogo & 3 & 0 & - \\
\hline & & Lagoa do Pico da Lagoa & 83 & 0 & - \\
\hline & & Lagoa do Pau Pique & 207 & 0 & - \\
\hline & & Lagoa do Areeiro & 2,781 & 0.01 & $1-5$ \\
\hline
\end{tabular}

${ }^{a}$ Prevalence is presented here as a proportion

Nomenclature and measurements used here follow Zawal in his extensive studies of Arrenurus larvae (see Zawal 2008b and references therein). Voucher specimens are deposited in the water mite collection of the MNCN (Madrid).

\section{Results}

Mite species infesting Ischnura hastata at the Azores

Morphological data for L. killingtoni collected in Pico are shown in Appendix-Table 6. These specimens from the Azores (Fig. 1) differ from specimens previously collected in Spain in that they show a greater range variability of some measurements, mainly $\mathrm{W}$ (width of scutum), AW (distance between scutalae AL), PsGd (length of dorsal palpfemoral seta) and leg segments (Appendix-Table 7).

Mite larvae found parasitizing I. hastata from Lagoa do Areeiro in São Miguel Island have been identified as belonging to the genus Arrenurus (Acari, Hydrachnidia). Below, we describe the morphology of these mite larvae and identify them to the lowest taxonomic level possible; we also make some additional comments on these specimens.

\section{Arrenurus (Arrenurus) sp. (Fig. 2)}

Body shape from nearly round to elliptical depending on the engorgement state of the larvae (Fig. 2a, b). In the non-engorged specimens, the gnathosoma projects beyond the anterior end of the dorsal plate (Fig. 2b, c). Dorsal plate shield shaped, similar to A. affinis (Koenike, 1887), with anterior margin almost straight and covering nearly all of the idiosoma in the non-engorged specimen. Dorsal plate (Fig. 2b) with scale-like reticulation 
and with five pair of setae: Lp1 tripartite, the other four apparently smooth. Mp1-Mp1 distance longer than Mp2-Mp2. Ratio dorsal plate width/Mp1-Mp1 <3.2 (Zawal 2008a).

There is a pair of small eyes, clearly identifiable from their pigment, below the anterior part of the dorsal plate. In one specimen, the eye pigment extended beyond the eye plaque. Another pair of eyes is located laterally to the dorsal plate on eyes capsule, which have a small process in its posterior part.

Coxal plates I, II and III separated from one another by four pairs of setae (Fig. 2c) on each side and medially. The length of the median margin of the coxal plate II is the shortest. Distance between C1-Cp1 median margin about $1 / 2$ the distance between C4-Cp4 median margin. Excretory plate almost rounded with two pairs of setae, width slightly greater than length (Fig. 2d). Excretory pore closer to the anterior end of the excretory plate and slightly anterior to E2 setae.

Pedipalps five-segmentated and typical for Arrenurus species (Fig. 2f). PIII1 seta bipectinate, PV7 pectinated. Chelicerae bisegmentated (Fig. 2e). Legs with five movable segments (Fig. 2g, h). Total length of legs similar to the A. affinis (Koenike, 1887), A.neumani (Piersig, 1895), and A. vietsi (Koenike, 1911) species complex (Zawal 2008b). Metric values of the different morphological characters are shown in Appendix-Tables 7 and 8.

\section{Prevalence and intensity of infestation}

Prevalence of infestation by L. killingtoni was highly variable among the different ponds studied in Pico Island, ranging from 0 to $41 \%$ on I. hastata, and from 0 to $35 \%$ on I. pumilio. Parasite load was 1-12 mites per female in the case of I. hastata, and 1-4 mites

Table 3 Attachment sites of Leptus killingtoni and Arrenurus sp. upon Ischnura hastata. Data shown in the table correspond to 2008. For L. killingtoni, only data from the populations of Lagoa do Gato and Lagoa do Cabeço do Caveiro are shown

\begin{tabular}{lll}
\hline Mite species & Host site & Observed no. of mites
\end{tabular}

Leptus killingtoni

$\begin{array}{lr}\text { Legs } & 5 \\ \text { Abdomen segment I (SI) } & 3 \\ \text { Abdomen SII } & 1 \\ \text { Abdomen SIII } & 3 \\ \text { Abdomen SIV } & 3 \\ \text { Abdomen SV } & 1 \\ \text { Abdomen SVI } & 1 \\ \text { Abdomen SVII } & 1 \\ \text { Abdomen SVIII } & 2 \\ \text { Tip of abdomen } & 2 \\ \text { Thorax } & 5 \\ \text { Total } & 27\end{array}$

Arrenurus sp.

$\begin{array}{lr}\text { Ventral side of thorax, between legs } & 65 \\ \text { Space between thorax and abdomen } & 2 \\ \text { Mouth } & 4 \\ \text { Legs } & 1 \\ \text { Total } & 72\end{array}$




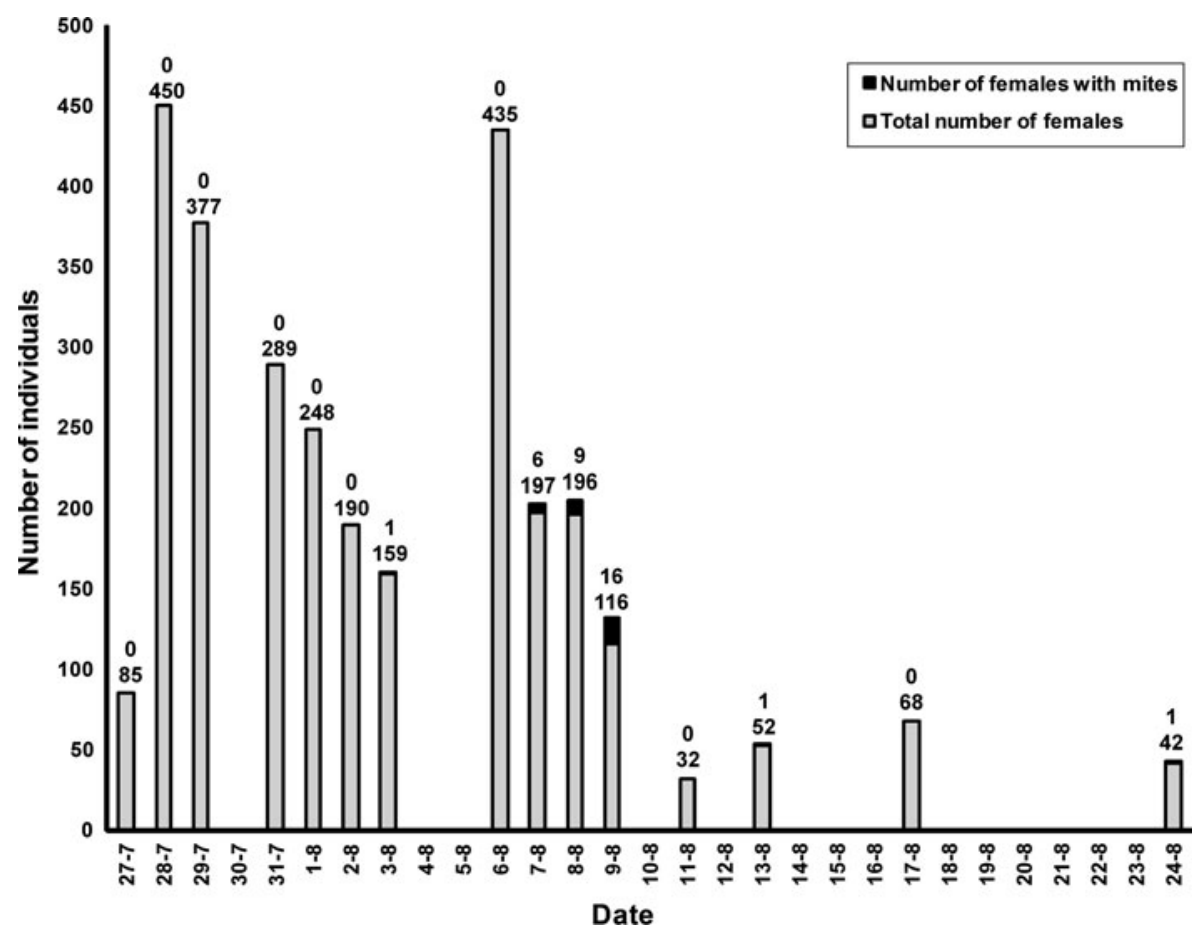

Fig. 3 Variation in the proportion of female Ischnura hastata parasitized by Arrenurus sp. at Lagoa do Areeiro, São Miguel, between 27 July and 24 August 2008. Numbers on bars indicate the number of infested females (above) and the total number of females captured each day (below)

in the case of I. pumilio (Table 1). In I. hastata females, L. killingtoni larvae attached predominantly to the abdominal segments (17 out of 27, Table 3), although some attached also to the thorax and legs (Table 3; Fig. 1). In one case a mite was found attached to the eye of a female I. hastata.

The prevalence of mite parasitism by Arrenurus sp. on I. hastata was very low. With the exception of one population in the island of São Miguel (Lagoa do Carvão), where 12\% of the collected females ( $n=17$, Table 2$)$ were parasitized, no mites were found in any of the 119 females collected in the Azores in 2003. Parasite load was two mites per individual in the samples collected in 2003 (Table 2). In 2008 we found a similar pattern, but in this year the females collected at Lagoa do Carvão $(n=35$, Table 2$)$ were not parasitized at all. Prevalence of mite parasitism in the population of Lagoa do Areeiro (São Miguel) was 1\%, considering both the females included in the mark-recapture study and the females previously collected and preserved in ethanol $(n=2,781$, Table 2$)$. Variation in the prevalence of parasitism was found in this population during the study period, ranging from $0.6 \%$ when the first parasitized females were observed to $2.4 \%$ at the end of the study, with a maximum of $13.8 \%$ (Fig. 3). Parasite load across the period was 1-5 mites per female (Table 2). Arrenurus sp. seems to select the ventral surface of the thorax, between the legs, as the main site of attachment (65 out of 72, Table 3, Fig. 2a), although two females had mites attached to the mouth and a female had one attached to a leg (Table 3).

Mites found on samples of sexual I. hastata collected in America had the typical morphology of Hydrachnidia, and were found attached also to the ventral surface of the 
Table 4 Prevalence of mite parasitism in sexual Ischnura hastata collected at different localities in America. Listed are: year of sample collection, locality, pond name, number of both males and females analyzed $(n)$, prevalence of parasitism $(\mathrm{P})$ and range in mite load (I)

\begin{tabular}{|c|c|c|c|c|c|c|c|}
\hline \multirow[t]{2}{*}{ Year } & \multirow[t]{2}{*}{ Locality } & \multirow[t]{2}{*}{ Pond } & \multicolumn{2}{|c|}{ Males } & \multicolumn{2}{|c|}{ Females } & \multirow[t]{2}{*}{ I } \\
\hline & & & $n$ & $\mathrm{P}^{\mathrm{a}}$ & $n$ & $\mathrm{P}^{1}$ & \\
\hline \multirow[t]{3}{*}{2003} & Vero Beach (Florida) & Baptist church pond & 3 & 0.33 & 38 & 0.08 & $1-4$ \\
\hline & & Unitarian universalist fellowship pond & 16 & 0 & 8 & 0.13 & 1 \\
\hline & & West airport pond & 2 & 0 & 13 & 0.08 & 1 \\
\hline 2004 & Vicam (México) & Unnamed pond & 7 & 0 & 24 & 0 & \\
\hline 2007 & Santiago de Cuba & Unnamed pond & & & 22 & 0 & \\
\hline \multirow[t]{4}{*}{2010} & Santiago de Cuba & Unnamed pond & & & 8 & 0 & \\
\hline & Santiago de Cuba & Mola & 18 & 0 & 17 & 0 & \\
\hline & Santiago de Cuba & La Redonda & 13 & 0 & 22 & 0 & \\
\hline & Bucaramanga (Colombia) & Humedal El Pantano & 16 & 0 & 32 & 0.06 & $1-2$ \\
\hline
\end{tabular}

${ }^{\text {a }}$ Prevalence is presented here as a proportion

thorax of their hosts. As for the parthenogens, prevalence of parasitism in the sexual populations examined was low. In the samples collected in Colombia, prevalence of parasitism was $6 \%$ for females $(n=32$, Table 4$)$, whereas no mites were found on males ( $n=16$, Table 4). Mite load in this population was 1-2 mites per female. In the three populations from Florida examined, prevalence of parasitism for females varied between 8 and 13\% (Table 4). In two of these populations no mites were found on males, and in one population one out of three males (Table 4) was infested. Mite load in these populations ranged from 1 to 4 mites per individual. No mites were found on the individuals collected in Mexico and Cuba (Table 4).

\section{Discussion}

Two very different mites parasitize parthenogenetic I. hastata at the Azores. The most prevalent is L. killingtoni, a terrestrial mite already known from Pico Island, where it was found on the caterpillar Pseudaletia (=Mythimna) unipuncta (Haworth, 1809) (McNeill and Treat 1992). Larvae of this mite species have been previously reported as parasites of Odonata, with the following species reported as hosts in Great Britain (Turk 1945): Pyrrhosoma nymphula (Sulzer, 1776), Enallagma cyathigerum (Charpentier, 1840), Coenagrion puella (Linnaeus, 1758), Ceriagrion tenellum, Lestes sponsa (Hansemann, 1823), Cordulegaster boltonii (Donovan, 1807), Anax imperator Leach, 1815, and Orthetrum coerulescens (Fabricius, 1798). Herein we reported the prevalence of this mite on I. hastata and I. pumilio from Pico, but we have also observed these mites on Sympetrum fonscolombii (Selys, 1840) at the same island. The latter three species are new hosts for L. killingtoni.

The greatest number of L. killingtoni larvae that we recorded on an I. hastata individual was 12 (Table 1), although one female with a higher parasite load was observed (Fig. 1a). A similar number of mites (eight) has been previously recorded in odonates from the UK (Turk 1945), which suggests that the effect of this terrestrial mite on odonates should be 
less intense than the effect of water mites, whose loads can be in some cases much higher than 100 (Anderson and Anderson 1998; Table 5).

The second type of mite found associated with I. hastata were water mites found at the island of São Miguel. Only two genera of water mites have been mentioned for the Azores: Sperchon and Arrenurus (Viets 1978; Raposeiro et al. personal communication). The specimens found on I. hastata conform to the morphological characteristics of the larvae of Arrenurus as described by Zawal (2008a) in his monograph on Arrenurus larvae, but they do not conform to any of the previously described larvae, and thus our description is given as reference. To be certain of the specific identity of a water mite larva it is necessary to associate the adult female with the hatched eggs. This has not been possible with the mites found on I. hastata, and thus the larvae have been identified to the lowest category possible. These specimens have the diagnostic characteristics that identify them as belonging to the subgenus Arrenurus (Arrenurus). Although approximately 170 species of Arrenurus were described from Europe and about 400 from the world, the larval stage of no more than 70 are known. In the Azores, only A. chavesi has been recorded, but this species is presently considered incertae sedis (Viets 1987). From the general morphology of the dorsal and ventral shields, our specimens from São Miguel are closest to the A. affinis, A. neumani and A. vietsi group, whose larvae are indistinguishable (Zawal 2008b). Thus, to identify these larval mites at the specific level we must wait for the finding of some adult specimens.

The prevalence of mite parasitism in adult Odonata varies between years, populations, and individuals within populations (Corbet 1999). Factors such as differences in host exposure, immunity, phenology and spatial constraints also influence field variation in parasitism by water mites (Lajeunesse et al. 2004; Lajeunesse 2007). In the present study, the prevalence of infestation of parthenogenetic I. hastata by Arrenurus sp. was low, but comparable to what we have observed in the samples from sexual populations examined from the Americas (see Table 4). Published records of mite parasitism for different Coenagrionidae species are shown in Table 5. These data reveal that the prevalence of parasitism on I. hastata is in general lower than that observed in other damselfly species. Our estimates of parasitism in the samples of $I$. hastata from sexual populations are similar to previously published estimates for this species (Lajeunesse 2007; see Tables 4 and 5).

With respect to the attachment sites, we have found a tendency of aquatic mite larvae to attach to the ventral surface of the thorax, a pattern that has previously been reported for Arrenurus larvae (Smith 1988). In the case of L. killingtoni, most larvae were found attached to the host's abdomen, although sometimes to the thorax, legs and even head and eyes, suggesting that L. killingtoni does not show a clear preference when attaching to their hosts, an observation already reported for this genus (Baker 1982).

The low prevalence of parasitism found in the sexual I. hastata populations may be due to the habitat characteristics of this species, or simply to the lack of temporal and spatial co-occurrence of I. hastata with the mite larvae. In order to better assess the impact of mite parasitism in this species, it would be necessary to compare the prevalence of parasitism in different habitat types from the same locations. In the case of the parthenogenetic populations, we have found that the prevalence of mite parasitism is also very low, and at most of the studied ponds, no mites were found attached to odonates. The data collected at Lagoa do Areeiro (São Miguel) suggest differences in phenology between I. hastata and Arrenurus sp., since the maximum prevalence of parasitism in this population was observed at the end of the study period, when the number of I. hastata females in the population had diminished. Alternatively, the low prevalence of parasitism found in the Azores could simply be explained by the scarcity of parasites in the archipelago. 


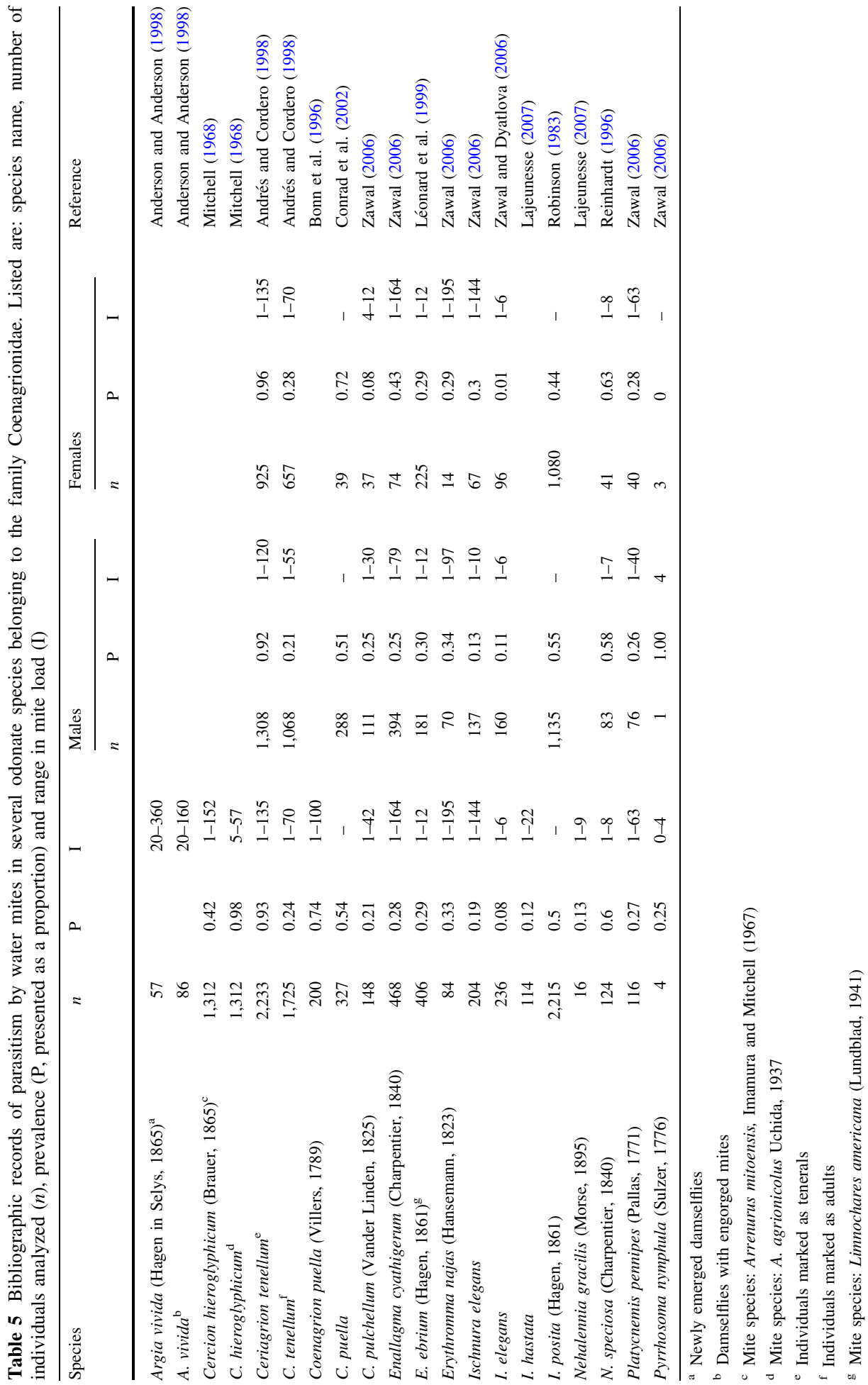


In the light of the Red Queen Hypothesis (Van Valen 1973; Bell 1982; Ridley 1995), we would predict that I. hastata in the Azores, with its asexual reproduction and very low genetic diversity (Lorenzo-Carballa et al., submitted), would be less able to evolve resistance to parasites, and would thus host higher parasite loads than sexual populations (Bell 1982; Ridley 1995). However, we did not find this pattern, though this could be due to the overall lower abundances of parasites in the Azores, rather than a heightened resistance to mite parasitism in these asexual populations One possible solution to this problem is to compare parasitism rates in parthenogenetic I. hastata with those of sexual I. pumilio, which are also found in the Azores. Unfortunately these two species were rarely found coexisting in large numbers, and the data available for this comparison (see Table 1), although suggestive, do not allow us to test the predictions of the Red Queen Hypothesis. Besides, using adult damselflies to estimate mite infection intensity might not be meaningful. For example, it has been proved that underwater oviposition, a common behavior in I. hastata at the Azores (Lorenzo-Carballa et al. 2009), favors detachment of water mites in damselflies (Rolff 1997). Further studies should concentrate on detecting mites in immature females. In the case of L. killingtoni, we have observed that the mites easily detached from their hosts when captured in the net (Lorenzo-Carballa and CorderoRivera, personal observations). All these facts suggest that our estimates of prevalence of mite parasitism are likely to be underestimates, and thus the comparative analysis of mite parasitism could be an unsuitable system to study questions related to parasites and the evolution of sex. In this respect, a comparative investigation of the distribution and virulence of endoparasites might be revealing. For example, gregarines have been reported as parasites of seven different families of Odonata, and larvae of the mermithid Linstowimermis (=Amphimermis) tinyi (Nickle, 1972) have been described as parasites of I. hastata nymphs (Corbet 1999). Future research should be directed towards a comparative analysis of parasitism rates between both species in several ponds at the Azores. Thus, the parthenogenetic populations of I. hastata in the Azores may still lead to new findings concerning the Red Queen Hypothesis in the future.

In conclusion, the low prevalence of mite parasitism found in the Azores, coupled with the fact that most of the populations in the archipelago are almost free from competitors and predators (Lorenzo-Carballa et al. 2009) could explain the persistence of the I. hastata parthenogenetic populations, despite their low levels of genetic variation. This example adds new evidence to the idea of the islands as suitable habitats for the persistence of parthenogenetic reproduction (Whittaker and Fernández-Palacios 2007).

Acknowledgments Funding was provided by the Spanish Ministry of Science and Innovation (grant CGL2005-00122, including FEDER funds, to ACR, and grant CGL2009-08943 to AGV). We thank the Instituto para a Conservaçao da Natureza (Lisbon) and the Secretaria Regional do Ambiente e do Mar (Faial Island, Azores) for permits to collect damselflies. Many thanks to all the people that helped during field work: Inés González de Castro and Kathleen Harding in the Azores; Laura Sirot in Florida; Alejandro Córdoba-Aguilar, Sandy Upson, Robert Behrstock and Doug Danforth in Mexico; Yusdiel Torres-Cambas and Adrián Trapero in Cuba; and Melissa Sánchez Herrera and Emilio Realpe in Colombia. A. Zawal and P. Martin kindly provided us with copies of their papers on arrenurid larvae. SEM analysis of mites was done with the help of Jesús Méndez and Inés Pazos from the "Centro de Apoio Científico e Tecnolóxico á Investigación" (CACTI, Universidade de Vigo).

\section{Appendix}

See Tables 6, 7 and 8 . 
Table 6 Metric data of Leptus killingtoni larvae from: Great Britain (Southcott 1992), Spain (Haitlinger 2006) and Azores (this work). Abbreviations used here are explained in Southcott (1992) and Haitlinger (2006). All measurements are given in micrometers

\begin{tabular}{|c|c|c|c|c|c|c|c|}
\hline & $\begin{array}{l}\text { G. Britain } \\
(n=1)\end{array}$ & $\begin{array}{l}\text { Spain } \\
(n=10)\end{array}$ & $\begin{array}{l}\text { Azores } \\
(n=10)\end{array}$ & & $\begin{array}{l}\text { G. Britain } \\
(n=1)\end{array}$ & $\begin{array}{l}\text { Spain } \\
(n=10)\end{array}$ & $\begin{array}{l}\text { Azores } \\
(n=10)\end{array}$ \\
\hline IL & & $362-806$ & $406-756$ & TiI & 145 & $134-148$ & $138-160$ \\
\hline IW & & $202-571$ & $305-540$ & GeI & 114 & $100-108$ & $92-116$ \\
\hline $\mathrm{L}$ & & 90-104 & $80-102$ & TfI & & $66-70$ & $62-72$ \\
\hline W & 114 & $96-102$ & $96-114$ & BfI & & $72-84$ & $70-92$ \\
\hline AW & 78 & $72-78$ & $74-88$ & $\operatorname{TrI}$ & & $44-50$ & $42-54$ \\
\hline PW & 103 & $86-90$ & $88-102$ & CxI & & $58-70$ & $62-72$ \\
\hline AA & 15 & $10-12$ & $8-12$ & TaII & 113 & $114-124$ & $104-122$ \\
\hline SB & 20 & $14-16$ & $12-20$ & TiII & 136 & $120-130$ & $110-134$ \\
\hline AL. & 57 & $70-84$ & $68-76$ & GeII & 100 & $84-90$ & 84-100 \\
\hline PL & 64 & $66-76$ & $64-80$ & TfII & & $62-80$ & $58-72$ \\
\hline AM & 46 & $40-50$ & $40-54$ & BfII & & $60-78$ & $62-78$ \\
\hline$S$ & 64 & $62-72$ & $60-84$ & TrII & & $42-54$ & $42-50$ \\
\hline $\mathrm{AP}$ & 18 & $12-18$ & $12-18$ & CxII & & $80-90$ & $80-92$ \\
\hline ISD & 49 & $50-56$ & $52-60$ & TaIII & 129 & $110-122$ & $110-128$ \\
\hline GL & & $156-172$ & $154-178$ & TiIII & 182 & $164-176$ & $158-180$ \\
\hline Ds. & $46-60$ & $38-62$ & $38-60$ & GeIII & 109 & $92-106$ & $92-106$ \\
\hline $1 \mathrm{a}$ & & $48-58$ & $48-60$ & TfIII & & $72-78$ & $68-80$ \\
\hline $2 \mathrm{a}$ & & $42-60$ & $48-64$ & BfIII & & $76-90$ & $72-90$ \\
\hline $1 b$ & & $66-82$ & $70-82$ & TrIII & & $52-54$ & $46-54$ \\
\hline $2 b$ & & $38-44$ & $34-42$ & CxIII & & $72-84$ & $80-92$ \\
\hline $3 b$ & & $50-58$ & $48-58$ & $\operatorname{leg} \mathrm{I}$ & & & $604-682$ \\
\hline PsFd & & $54-78$ & $58-74$ & leg II & & & $554-634$ \\
\hline PsGd & & $42-54$ & $46-62$ & $\begin{array}{r}\text { Leg } \\
\text { III }\end{array}$ & & & $642-712$ \\
\hline TaI & 120 & $114-126$ & $112-132$ & Ip & & & $1,800-2,028$ \\
\hline
\end{tabular}

Table 7 Arrenurus sp. larvae. Lengths of body parts $(n=3)$. Nomenclature and measurements used follow Zawal (2008b): Cp coxal plate, Exp excretory pore, Expp excretory pore plate, PI-PV segments on pedipal; for setae Mp1, Lp1, Lp2, Mh1 and C1-C4 see Fig. 2. All measurements are given in micrometers

\begin{tabular}{lrrr}
\hline & N1 & N2 & N3 \\
\hline Body length & 240 & 414 & 311 \\
Body width & 219 & 370 & 266 \\
Dorsal plate length & 224 & 208 & 231 \\
Dorsal plate width & 165 & $166^{*}$ & 166 \\
CpI medial margin length & 76 & 78 & $76^{* *}$ \\
CpII medial margin length & 30 & 38 & $34^{* *}$ \\
CpIII medial margin length & 41 & 48 & $38^{* *}$ \\
Distance: Mp1-Mp1 & 59 & 59 & 59 \\
Distance: Lp1-Lp1 & 65 & 69 & 70 \\
Distance: Lp2-Lp2 & 90 & 98 & 96 \\
\hline
\end{tabular}


Table 7 continued

\begin{tabular}{|c|c|c|c|}
\hline & N1 & $\mathrm{N} 2$ & N3 \\
\hline Distance: Mp2-Mp2 & 52 & 58 & 53 \\
\hline Distance: Mh1-Mp2 & 48 & 48 & 45 \\
\hline Distance: Mp1-Lp1 & 10 & $7 *$ & 13 \\
\hline Distance: Mp1-Lp2 & 44 & $38^{*}$ & 48 \\
\hline Distance: Mp1-Mp2 & 80 & $62 *$ & 80 \\
\hline Distance between $\mathrm{C} 1$ and $\mathrm{CpI}$ median margin & 22 & 23 & 21 \\
\hline Distance between $\mathrm{C} 4$ and $\mathrm{CpIII}$ median margin & 40 & 44 & 46 \\
\hline Distance between $\mathrm{C} 1$ and $\mathrm{C} 2$ & 57 & 57 & 57 \\
\hline Excretory pore plate length & 27 & 28 & 25 \\
\hline Excretory pore plate width & 29 & 30 & 28 \\
\hline Distance between Exp and Expp posterior margin & 17 & 17 & 15 \\
\hline Distance between E1 setae and Expp anterior margin & 4 & 5 & 4 \\
\hline Distance between E2 setae and Expp posterior margin & 10 & 10 & 11 \\
\hline PI length & 8 & 12 & \\
\hline PII length & 33 & 38 & \\
\hline PIII length & 31 & 32 & \\
\hline Length of PIV claw & 28 & & \\
\hline Length of cheliceral segment I & 112 & & \\
\hline
\end{tabular}

* Figures underestimate real length due to curvature of the structure

** Limits of these measurements are somewhat arbitrary, especially in CpIII

Table 8 Arrenurus sp. larvae. Lengths of body parts $(n=3)$. Nomenclature and measurements used here follow Zawal (2008b). All measurements are given in micrometers

\begin{tabular}{lllllll}
\hline & & Trochanter & Femur & Genu & Tibia & Tarsus \\
\hline N1 & Leg 1 & 30 & 40 & 44 & 61 & 95 \\
& Leg2 & 40 & 46 & 48 & 65 & 97 \\
N2 & Leg 3 & 48 & 48 & 46 & 70 & 97 \\
& Leg1 & 40 & 42 & 46 & 63 & 91 \\
& Leg2 & 36 & 42 & 46 & 65 & 99 \\
N3 & Leg3 & 44 & 40 & 46 & 68 & 97 \\
& Leg 1 & 34 & 38 & 40 & 61 & 95 \\
& Leg 2 & 32 & 40 & 48 & 63 & 97 \\
& Leg 3 & 38 & 34 & 42 & 66 & 95 \\
\hline
\end{tabular}

\section{References}

Anderson TM, Anderson NH (1998) The life history of Arrenurus hamrumi, a water mite from rangeland springs in Oregon, USA. In: Botosaneanu L (ed) Studies in crenobiology. Backhuys Publishers, The Netherlands, pp 63-74

Andrés JA, Cordero A (1998) Effects of water mites on the damselfly Ceriagrion tenellum. Ecol Entomol 23:103-109 
Baker GT (1982) Site attachment of a protelean parasite (Erythraeidae: Leptus sp.). Experientia 38:923

Bell G (1982) The Masterpiece of Nature: The Evolution and Genetics of Sexuality. University of California Press, Berkeley

Bonn A, Gasse M, Rolff J, Martens A (1996) Increased fluctuating asymmetry in the damselfly Coenagrion puella is correlated with ectoparasitic mites: implications for fluctuating asymmetry theory. Oecologia 108:596-598

Braune P, Rolff J (2001) Parasitism and survival in a damselfly: does host sex matter? Proc R Soc Lond B Biol Sci 268:1133-1137

Clay K, Kover PX (1996) The Red Queen hypothesis and plant/pathogen interactions. Ann Rev Phytopatol 34:29-50

Conrad KF, Willson KH, Whitfield K, Harvey IF, Thomas CJ, Sherratt TN (2002) Characteristics of dispersing Ischnura elegans and Coenagrion puella (Odonata): age, sex, size, morph and ectoparasitism. Ecography 25:439-445

Corbet PS (1999) Dragonflies. Behaviour and Ecology of Odonata. Harley Books, Essex

Cordero Rivera A, Lorenzo Carballa MO, Utzeri C, Vieira V (2005) Parthenogenetic Ischnura hastata (Say, 1839), widespread in the Azores islands (Zygoptera: Coenagrionidae). Odonatologica 34:1-9

Grant PBC, Samways MJ (2007) Ectoparasitic mites infest common and widespread but not rare and redlisted dragonfly species. Odonatologica 36:255-262

Haitlinger R (1987) Larval Erythraeidae (Acari, Prostigmata) from Madagascar. Polskie Pismo Entomologiczne 57:701-723

Haitlinger R (2006) New records of larval mites (Acari: Prostigmata: Erythraeidae, Eutrombidiidae, Trombidiidae) from Portugal and Spain. Revista Ibérica de Aracnología 14:105-108

Hamilton WD, Axelrod R, Tanese R (1990) Sexual reproduction as an adaptation to resist parasites (a review). Proc Natl Acad Sci USA 87:3566-3573

Hanley KA, Fisher RN, Case TJ (1995) Lower mite infestations in an asexual gecko compared with its sexual ancestors. Evolution 49:418-426

Lajeunesse MJ (2007) Ectoparasitism of damselflies by water mites in Central Florida. Florida Entomologist 90:643-649

Lajeunesse MJ, Forbes MR, Smith BP (2004) Species and sex biases in ectoparasitism of dragonflies by mites. Oikos 106:501-508

Léonard NJ, Forbes MR, Baker RL (1999) Effects of a mite, Limnochares americana (Hydrachnidia: Limnocharidae), on the life-history traits and grooming behaviour of its damselfly host, Enallagma ebrium (Odonata: Coenagrionidae). Can J Zool 77:1615-1622

Lively CM, Craddock C, Vrijenhoek RC (1990) Red Queen hypothesis supported by parasitism in sexual and clonal fish. Nature 344:864-866

Lorenzo-Carballa MO, Cordero-Rivera A (2009) Thelytokous parthenogenesis in the damselfly Ischnura hastata (Odonata, Coenagrionidae): genetic mechanisms and lack of bacterial infection. Heredity 103:377-384

Lorenzo-Carballa MO, Beatty CD, Utzeri C, Vieira V, Cordero-Rivera A (2009) Parthenogenetic Ischnura hastata revisited: present status and notes on population ecology and behaviour (Odonata: Coenagrionidae). Int J Odonatol 12:395-411

Martin P (2006) On the morphology and classification of larval water mites (Hydrachnidia, Acari) from springs in Luxembourg. Zootaxa 1138:1-44

McNeill JN, Treat AE (1992) Mites associated with the true armyworm, Pseudaletia unipuncta (Lepidoptera: Noctuidae), in the Azores. Int J Acarology 18:143-144

Mitchell R (1968) Site selection by larval water mites parasitic on the damselfly Cercion hieroglyphicum Brauer. Ecology 49:40-47

Moritz C, McCallum H, Donnellan S, Roberts JD (2010) Parasite loads in parthenogenetic and sexual lizards (Heteronotia binoei): support for the Red Queen Hypothesis. Proc Roy Soc B: Biol Sci 244:145-149

Reinhardt K (1996) Negative effects of Arrenurus water mites on the flight distances of the damselfly Nehalennia speciosa (Odonata: Coenagrionidae). Aquatic Insects 18:233-240

Ridley M (1995) The red queen: sex and the evolution of human nature. Penguin Books, London

Robinson JV (1983) Effects of water mite parasitism on the demographics of an adult population of Ischnura posita (Hagen) (Odonata: Coenagrionidae). Am Midl Nat 109:169-174

Rolff J (1997) Better hosts dive: detachment of ectoparasitic water mites (Hydrachnellae: Arrenuridae) from damselflies (Odonata: Coenagrionidae). J Insect Behavior 10:819-827

Salathé M, Kouyos RD, Bonhoeffer S (2008) The state of affairs in the Kingdom of the Red Queen. Trends Ecol Evol 23:439-445

Smith BP (1988) Host-parasite interaction and impact of larval water mites on insects. Annu Rev Entomol 33:487-507 
Smith IM, Cook DR, Smith BP (2009) Water mites (Hydrachnidiae) and other Arachnids. In: Thorp JH, Covich AP (eds) Ecology and classification of North American freshwater invertebrates. Academic Press, New York

Southcott RV (1966) Revision of the genus Charletonia Oudemans (Acarina: Erythraeidae). Aust J Zool 14:687-819

Southcott RV (1992) Revision of the larvae of Leptus Latreille (Acarina: Erythraeidae) of Europe and North America, with descriptions of post-larval instars. Zool J Linn Soc 105:1-153

Southcott RV (1999) Larvae of Leptus (Acarina: Erythraeidae), free-living or ectoparasitic on arachnids and lower insects of Australia and Papua New Guinea, with descriptions of reared post-larval instars. Zool J Linn Soc 127:113-276

Turk FA (1945) Studies of Acari. Second series: descriptions of new species and notes on established forms of parasitic mites. Parasitology 36:133-141

Van Valen L (1973) A new evolutionary law. Evol Theory 1:1-30

Viets KO (1978) Hydracarina. In: Illies J (ed) Limnofauna Europaea. Gustav Fischer, Stuttgart, pp 154-181

Viets KO (1987) Die Milben des Süßwassers (Hydrachnellae und Halacaridae (part.), Acari). II.: Katalog. Sonderbände des Naturwiss. Vereins Hamburg 8:1-1012

Westfall MJ, May ML (1996) Damselflies of North America. Scientific Publishers, Gainesville

Whittaker RJ, Fernández-Palacios JM (2007) Island biogeography. Ecology, evolution and conservation. Oxford University Press, Oxford

Zawal A (2006) Phoresy and parasitism: water mite larvae of the genus Arrenurus (Acari: Hydrachnidia) on Odonata from Lake Binowskie (NW Poland). Biol Lett 43:257-276

Zawal A (2008a) Morphological characteristics of water mite larvae of the genus Arrenurus Dugès, 1834, with note on the phylogeny of the genus and an identification key. Zootaxa 1765:1-75

Zawal A (2008b) Morphology of the larval stages of Arrenurus affinis Koenike, 1887, A. neumani Piersig, 1895, and A. vietsi Koenike, 1911 (Acari: Hydrachnidia). Genus 19:161-169

Zawal A, Dyatlova ES (2006) Preliminary data for parasitizing on Ischnura elegans (Vander Linden, 1820) (Odonata: Coenagrionidae) by Arrenurus (Acari: Hydrachnidia) larvae from Odessa province (Southwestern Ukraine). In: Pešić V, Hadžiablahovič S (eds) Proceedings of the Symposium, II International Symposium of Ecologists of Montenegro. Kotor, pp 17-20

Zawal A, Dyatlova ES (2008) Parasitizing on damselflies (Odonata: Coenagrionidae) by water mites (Acari: Hydracnidia) larvae from Odessa province (Southwestern Ukraine) Natura Montenegrina. Podgorica 7:453-462

Zheng B (1996) Two new larval mites of the Erythraeidae from China (Acari: Prostigmata). Acta Zootaxonomica Sinica 21:62-69 